\title{
Prevention by care and treatment of HIV-positive pregnant woman in Côte d'Ivoire
}

\author{
Kouamé Hervé Aka Prao*, Nicole Dakoury, Pety Touré, Nafissa Diakité, Koko Régina Konan, \\ Marie-france Coulibaly Anaky, Siaka Touré, Irma Ahoba Bobo \\ From $16^{\text {th }}$ International Symposium on HIV and Emerging Infectious Diseases \\ Marseille, France. 24-26 March 2010
}

\section{Background}

Côte d'Ivoire is a west Africa country. With a HIV prevalence of $8.6 \%$ among pregnant women and 661,000 births per year, Cote d'Ivoire has an estimated 55,000 HIV-infected women delivering per year who need PMTCT services. ACONDA's extension of decentralized prevention and care for pregnant women and PLWHA is based on a health district approach.

\section{Methods}

Health workers were trained. After, the program strategy consisted in coaching the care providers at the sites in VCT techniques with rapid HIV testing for women with unknown HIV status in ANC, labor-and-delivery rooms and Family Planning unit also.

Drawing up and spreading simple technical procedures helped the care providers in the implementation of PMTCT.

The combined prophylaxis was offered to HIVinfected pregnant women and their newborns systematically, as recommended by national program, and then she got initial biological exams. Those who were eligible received a readjusted treatment. Those who were ineligible continued the current disease prevention. A psychosocial supports for treatment adherence, was provided by counselors and Nutritional advices also. A child's early HIV diagnosis by PCR is made after 6 weeks of postnatal follow up.

\section{Results}

From January through November 2008, PMTCT services were integrated into 70 ANC clinics in urban areas and 20 in rural areas, covering 23 districts, with 100 trained

* Correspondence: praoerv@yahoo.fr

NGO ACONDA VS, Abidjan, Cote D'Ivoire health workers. Of 54,876 pregnant women using antenatal services, 45,730 (83.33\%) received HIV counseling and testing; 3100 (6.77\%) were HIV-positive; and 3,000 infected pregnant women (96\%) received their test results. $78 \%$ of HIV-infected women received the mother and child combined prophylaxis against $68 \%$ in 2007. Among the HIV-infected women, 520 were eligible for ART according to the WHO criteria.

\section{Discussion}

Providing the combined prophylaxis from the disclosure of test results is essential if we noticeably want to reduce the Mother to child HIV Transmission for the scaling up. Without intervention in our country, the rate of transmission is between $30-40$ per cent.

Published: 11 May 2010

doi:10.1186/1742-4690-7-S1-P156

Cite this article as: Prao et al.: Prevention by care and treatment of HIVpositive pregnant woman in Côte d'Ivoire. Retrovirology 2010 7(Suppl 1): P156.

Submit your next manuscript to BioMed Central and take full advantage of:

- Convenient online submission

- Thorough peer review

- No space constraints or color figure charges

- Immediate publication on acceptance

- Inclusion in PubMed, CAS, Scopus and Google Scholar

- Research which is freely available for redistribution

Submit your manuscript at www.biomedcentral.com/submit
C Biomed Central 